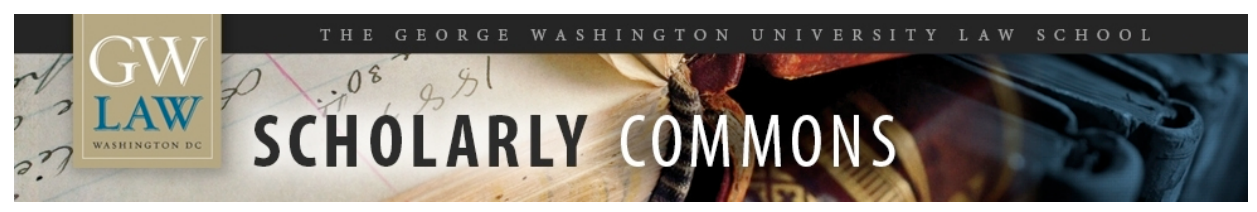

\title{
Peremptory Norms of General International Law (Jus Cogens) and Other Topics: The Seventy- First Session of the International Law Commission
}

Sean D. Murphy

George Washington University Law School, smurphy@law.gwu.edu

Follow this and additional works at: https://scholarship.law.gwu.edu/faculty_publications

Part of the Law Commons

\section{Recommended Citation}

Murphy, Sean D., Peremptory Norms of General International Law (Jus Cogens) and Other Topics: The Seventy-First Session of the International Law Commission, American Journal of International Law, vol. 114, p. 68 (forthcoming 2020).

This Article is brought to you for free and open access by the Faculty Scholarship at Scholarly Commons. It has been accepted for inclusion in GW Law Faculty Publications \& Other Works by an authorized administrator of Scholarly Commons. For more information, please contact spagel@law.gwu.edu. 


\title{
CURRENT DEVELOPMENTS
}

\section{Peremptory Norms of General InTERnATIONAL LaW (Jus Cogens) AND Other TOPICS: THE SEVENTY-FIRST SESSION OF THE INTERNATIONAL LAW COMMISSION}

\author{
By Sean D. Murphy*
}

The International Law Commission (ILC) held its seventy-first session from April 29 to June 7 and from July 8 to August 9, 2019 in Geneva, under the chairmanship of Pavel Šturma (Czech Republic). ${ }^{1}$ Notably, the Commission completed the first reading of its topic on peremptory norms of general international law (jus cogens). The Commission also completed the first reading of its topic on protection of the environment in relation to armed conflict and completed the second reading of its topic on crimes against humanity.

Progress was also made in developing draft articles on succession of states with respect to state responsibility, draft articles on immunity of state officials from foreign criminal jurisdiction, and draft conclusions on general principles of law. Additionally, the Commission held informal consultations concerning model clauses for its topic on provisional application of treaties, the first reading of which was completed in the seventieth session and the second reading of which is expected during the seventy-second session in 2020.

The Commission added to its agenda a topic on sea-level rise in relation to international law, which is being addressed in the context of a study group rather than by use of a special rapporteur. It also added two new topics to its long-term work program: (1) reparation to individuals for gross violations of international human rights law and serious violations of international humanitarian law; and (2) prevention and repression of piracy and armed robbery at sea.

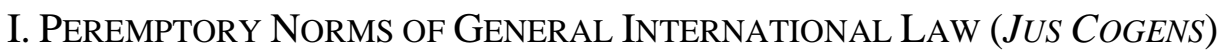

Twenty-three draft conclusions and draft annex for its topic on peremptory norms of general international law (jus cogens) were completed on first reading during the seventy-first session, under the guidance of special rapporteur Dire Tladi (South Africa). ${ }^{2}$ During the session, the Commission had before it the special rapporteur's fourth report, which principally focused on

\footnotetext{
* Manatt/Ahn Professor of International Law, George Washington University, and member of the UN International Law Commission. My thanks to Alexandra Utech (JD 2020) for assistance in preparing this essay.

${ }^{1}$ See Report of the International Law Commission on the Work of Its Seventy-First Session, UN GAOR, 74th Sess., Supp. No. 10, at 1-2, paras. 1, 3, UN Doc. A/74/10 (Sept. 16, 2019) [hereinafter 2019 Report]. This report and other International Law Commission documents are available online at http://legal.un.org/ilc. In addition, UN documents are generally available online at https://documents.un.org/prod/ods.nsf/home.xsp.

${ }^{2}$ For the complete set of draft conclusions and commentaries, see 2019 Report, supra note 1, at 142-208. For discussion of prior work on these conclusions, see Sean D. Murphy, Protection of Persons in the Event of Disasters and Other Topics: The Sixty-Eighth Session of the International Law Commission, 110 AJIL 718, 730-731 (2016) [hereinafter Murphy, Sixty-Eighth Session]; Sean D. Murphy, Crimes against Humanity and Other Topics: The Sixty-Ninth Session of the International Law Commission, 111 AJIL 970, 988-90 (2017) [hereinafter Murphy, Sixty-Ninth Session]; Sean D. Murphy, Anniversary Commemoration and Work of the International Law Commission's Seventieth Session, 113 AJIL 90, 100-103 (2019) [hereinafter Murphy, Seventieth Session].
} 
whether the Commission should adopt an "illustrative list" of jus cogens norms as a part of its draft conclusions. ${ }^{3}$

This full first draft of the "conclusions" consists of four parts and an annex. Part One contains three draft conclusions that address the scope of the project (draft conclusion 1), the definition of a peremptory norm of general international law (draft conclusion 2), and the general nature of such norms (draft conclusion 3). While draft conclusion $2^{5}$ essentially replicates the definition of jus cogens as found in the Vienna Convention on the Law of Treaties (VCLT), ${ }^{6} \mathrm{draft}$ conclusion 3 is more innovative ${ }^{7}$ and may prove controversial or confusing, especially if it is seen as requiring new criteria for identifying a norm as jus cogens.

Part $\mathrm{Two}^{8}$ of the draft conclusions address the identification of jus cogens. In doing so, this part of the draft conclusions may be seen as restating and embellishing upon the main components of the definition of jus cogens. Draft conclusion 4 restates the two criteria that are needed: (1) a norm of general international law; and (2) its acceptance and recognition by the international community of states as a whole as a norm from which no derogation is permitted and which can be modified only by a subsequent norm of general international law having the same character. Subsequent draft conclusions then embellish upon these criteria by indicating: the origins of jus cogens in customary international law, treaty provisions and general principles of law (draft conclusion 5); what is meant by "acceptance and recognition" (draft conclusion 6) and by "international community of States as a whole" (draft conclusion 7); and what forms of evidence might establish such acceptance and recognition, such as government legal opinions (draft conclusion 8). Finally, draft conclusion 9 notes subsidiary means for determining the peremptory character of norms of general international law: international courts and tribunals (national courts are not referenced), "works of expert bodies established by States or international organizations," and highly qualified publicists.

Part Three ${ }^{9}$ addresses the legal consequences of jus cogens. Three conclusions restate and reorganize aspects of the VCLT, so as to indicate the consequences that occur when a treaty conflicts with jus cogens, including in relation to separability and to the after-effects if a treaty is void $a b$ initio or becomes void due to the emergence of a jus cogens norm (draft conclusions 1012). Draft conclusion 13 indicates that a reservation to a treaty provision that reflects jus cogens

\footnotetext{
${ }^{3}$ See International Law Commission, Fourth Report on Peremptory Norms of General International Law ( Jus Cogens), UN Doc. A/CN.4/727 (Jan. 31, 2019) (prepared by Special Rapporteur Dire Tladi) [hereinafter Fourth Report on Peremptory Norms of General International Law]. The Fourth Report also considered whether there may exist "regional jus cogens," a concept that the Commission ultimately elected not to address in the draft conclusions.

42019 Report, supra note 1, at 142.

${ }^{5}$ Draft conclusion 2 reads: "A peremptory norm of general international law (jus cogens) is a norm accepted and recognized by the international community of States as a whole as a norm from which no derogation is permitted and which can be modified only by a subsequent norm of general international law having the same character."

${ }^{6}$ Vienna Convention on the Law of Treaties, May 23, 1969, 1155 UNTS 331, 8 ILM 679 (1969) [hereinafter VCLT].

${ }^{7}$ Draft conclusion 3 reads: "Peremptory norms of general international law (jus cogens) reflect and protect fundamental values of the international community, are hierarchically superior to other rules of international law and are universally applicable."

82019 Report, supra note 1, at 142-43.

92019 Report, supra note 1, at 143-46.
} 
does not affect the binding nature of that norm, and further that a reservation may not exclude or modify the legal effect of a treaty in a manner contrary to jus cogens. Having addressed legal consequences in the context of treaties, the draft conclusions move on to address legal consequences in the context of customary international law (draft conclusion 14), unilateral acts of States (draft conclusion 15), and legal obligations created by acts of international organizations (draft conclusion 16). The last of these draft conclusions does not identify any specific international organization or organ thereof, but the commentary indicates several possible sources of such legally-binding acts: the UN General Assembly; the UN Security Council; the International Civil Aviation Organization; the World Trade Organization; the European Union; and the African Union. ${ }^{10}$ Thereafter, draft conclusions assert that jus cogens norms give rise to obligations erga omnes (draft conclusion 17), that circumstances precluding wrongfulness may not be invoked for acts not in conformity with jus cogens (draft conclusion 18), and that States shall cooperate to bring to an end serious breaches of jus cogens and shall not recognize as lawful a situation created by such a breach (draft conclusion 19).

This part also contains two important process-oriented draft conclusions. First, when it appears that there is a conflict between jus cogens and another rule of international law, "the latter is, as far as possible, to be interpreted and applied so as to be consistent with the former" (draft conclusion 20). Second, a state that invokes jus cogens as a ground for the invalidity or termination of a rule of international law cannot simply walk away from such a rule; it must notify the other states concerned and, if they object, must pursue dispute resolution with them (draft conclusion 21). An innovative aspect of such dispute resolution is that "[i]f no solution is reached within a period of twelve months, and the objecting State or States concerned offer to submit the matter to the International Court of Justice, the invoking State may not carry out the measure which it has proposed until the dispute is resolved." ${ }^{11}$ Neither the draft conclusion nor the commentary, however, indicates what outcome arises if the invoking state offers to take the matter to the Court and the other state(s) declines to do so.

Part Four 12 on "general provisions" contains two draft conclusions. Draft conclusion 22 says that the draft conclusions are "without prejudice to consequences that specific peremptory norms of general international law (jus cogens) may otherwise entail under international law." This draft conclusion was the outcome of discussions that arose from two controversial draft conclusions that were originally proposed by the special rapporteur, which attempted to have the Commission conclude that "States have a duty to exercise jurisdiction over offences prohibited by" jus cogens "where the offences are committed by the nationals of that State or on the territory under its jurisdiction" (proposed draft conclusion 22, paragraph 1) and that "[i]mmunity ratione materiae shall not apply to any offence prohibited by" jus cogens (proposed draft conclusion 23, paragraph 2). ${ }^{13}$ Neither proposal was acceptable to the Commission and therefore were replaced by the "without prejudice" clause contained in draft conclusion 22.

Draft conclusion 23 and the associated Annex read as follows:

102019 Report, supra note 1, at 188-89, paras. (2)-(4).

${ }^{11} I d$., at 146 (draft conclusion 21, para. 4).

122019 Report, supra note 1, at 143-46.

${ }^{13}$ See International Law Commission, Third Report on Peremptory Norms of General International Law (Jus Cogens), UN Doc. A/CN.4/714, at 68-69 (Feb. 12, 2018) (prepared by Special Rapporteur Dire Tladi). 


\section{Conclusion 23 \\ Non-exhaustive list}

Without prejudice to the existence or subsequent emergence of other peremptory norms of general international law (jus cogens), a non-exhaustive list of norms that the International Law Commission has previously referred to as having that status is to be found in the annex to the present draft conclusions.

\section{Annex}

(a) The prohibition of aggression;

(b) The prohibition of genocide;

(c) The prohibition of crimes against humanity;

(d) The basic rules of international humanitarian law;

(e) The prohibition of racial discrimination and apartheid;

(f) The prohibition of slavery;

(g) The prohibition of torture;

(h) The right of self-determination.

As is apparent from the text of draft conclusion 23, the Commission did not seek to provide a complete list of existing norms of jus cogens. Moreover, the Commission has not sought even to provide an illustrative list of existing norms of jus cogens, as had been proposed by the special rapporteur in his fourth report. That proposal was to have a single draft conclusion (no annex) commencing with a chapeau reading: "Without prejudice to the existence of other peremptory norms of general international law (jus cogens), the most widely recognized examples of peremptory norms of general international law (jus cogens) are: ...."14

Rather, the Commission has simply provided in draft conclusion 23 and the Annex a list of some ${ }^{15}$ of the norms that have been "referred to" in prior work of the Commission, without assessing whether those norms, as of 2019, are jus cogens or are properly formulated as such. Moreover, as is apparent from the associated commentary, ${ }^{16}$ that prior work: is invariably cursory in nature (there is no indication in each instance of the evidence for why a particular norm should be regarded as jus cogens); at times does not directly declare norms to be jus cogens; ${ }^{17}$ is sometimes inconsistent in the formulation of the same norm; ${ }^{18}$ and at times is not even the work of the Commission as a whole. ${ }^{19}$ As such, any use of this illustrative list necessarily must carefully

\footnotetext{
${ }^{14}$ Fourth Report on Peremptory Norms of General International Law, supra note 3, at 63, para. 137.

${ }^{15}$ For example, the Commission has previously referred to the prohibition of piracy as jus cogens, but that norm does not appear in the Annex. See 2019 Report, supra note 1, at 207, paras. (13).

162019 Report, supra note 1, at 203-07, paras. (1)-(14).

${ }^{17}$ For example, the Commission has used phrases such as "[there] seems to be widespread agreement" with regard to certain norms being jus cogens. See id., at 204-05, para. (4).

${ }^{18}$ For example, compare the formulation of the "law of the Charter concerning the prohibition of the use of force" with the formulation "the prohibition of aggressive use of force." See id., at 205, para. (5).

${ }^{19}$ For example, it includes the work of a study group. See id. The Commission's commentary even points to a reference by the Commission to a particular norm made during a first reading text, which was then deleted at second reading. See id., at 207, para. (13).
} 
consider the quality and consistency of the Commission's prior work, and then consider developments thereafter, if the goal is to assess the contemporary status of the norm in question. The essential problem that the Commission faced was that determining whether a particular norm is jus cogens is a very complex and, at times, controversial task which, had it been undertaken by the Commission for this project, might well have required years of further work, even for an illustrative list. Instead, the Commission deemed it preferable simply to recall prior references in its work to such norms.

Having completed the first reading, the Commission transmitted the draft conclusions, through the UN Secretary-General, to governments for comments and observations, with the request that they be submitted by December $2020 .^{20}$ The Commission is then expected to return to this topic for second reading in 2021, the final year of the Commission's quinquennium.

\section{PROTECTION OF THE ENVIRONMENT IN RELATION TO ARMED CONFLICT}

The topic on protection of the environment in relation to armed conflict was also completed on first reading during the seventy-first session, under the guidance of special rapporteur Marja Lehto (Finland). ${ }^{21}$ During the session, the Commission had before it the special rapporteur's second report. ${ }^{22}$

This full first draft of "principles" consists of five parts. The commentary explains that these principles contain "provisions of different normative value, including those that can be seen to reflect customary international law, and those of a more recommendary nature." ${ }^{23}$ Part One ${ }^{24}$ consists of two draft principles, one addressing the scope of the project (draft principle 1) and the other its purpose (draft principle 2), with the later stating that the "present draft principles are aimed at enhancing the protection of the environment in relation to armed conflict, including through preventive measures for minimizing damage to the environment during armed conflict and through remedial measures."

Part Two ${ }^{25}$ addresses "principles of general application," which are considered relevant to periods before, during and after armed conflict. Here, the draft principles address issues such as: adoption by "States, pursuant to their obligations under international law, [of] effective legislative, administrative, judicial and other measures to enhance the protection of the environment in relation

202019 Report, supra note 1, at 5, para. (15).

${ }^{21}$ For the complete set of draft conclusions and commentaries, see 2019 Report, supra note 1, at 215-96. For discussion of prior work on these conclusions, see Sean D. Murphy, Immunity Ratione Personae of Foreign Government Officials and Other Topics: The Sixty-Fifth Session of the International Law Commission, 108 AJIL 41, 55-56 (2014) [hereinafter Murphy, Sixty-Fifth Session]; Sean D. Murphy, The Expulsion of Aliens (Revisited) and Other Topics: The Sixty-Sixth Session of the International Law Commission, 109 AJIL 125, 143 (2015) [hereinafter Murphy, Sixty-Sixth Session]; Sean D. Murphy, Identification of Customary International Law and Other Topics: The Sixty-Seventh Session of the International Law Commission, 109 AJIL 822, 838-41 (2015) [hereinafter Murphy, Sixty-Seventh Session]; Murphy, Sixty-Eighth Session, supra note 2, at 731-32; Murphy, Sixty-Ninth Session, supra note 2, at 992; Murphy, Seventieth Session, supra note 2, YY-ZZ.

${ }^{22}$ See International Law Commission, Second Report on Protection of the Environment in Relation to Armed Conflict, UN Doc. A/CN.4/728 (Mar. 27, 2019) (prepared by Special Rapporteur Marja Lehto).

232019 Report, supra note 1, at 215, para. (3).

242019 Report, supra note 1, at 211.

252019 Report, supra note 1, at 211-212. 
to armed conflict" (draft principle 3); designation "areas of major environmental and cultural importance as protected zones" (draft principle 4); "appropriate measures, in the event of armed conflict, to protect the environment of territories that indigenous peoples inhabit" (draft principle 5 ); appropriate "provisions on environmental protection in agreements concerning the presence of military forces" (draft principle 6); consideration of the impact of peace operations (draft principle 7); and effect of displacement of persons by armed conflict on the environment (draft principle 8). Moreover, the draft principles reiterate the international responsibility of States for an internationally wrongful act in relation to an armed conflict that causes damage to the environment (draft principle 9), as well as steps that states should take at the national level to address corporate due diligence (draft principle 10) and corporate liability (draft principle 11) with respect to such harm.

Part Three ${ }^{26}$ identifies various principles applicable during armed conflict. It opens with a "Martens clause" for this topic, which reads: "In cases not covered by international agreements, the environment remains under the protection and authority of the principles of international law derived from established custom, from the principles of humanity and from the dictates of public conscience" (draft principle 12). Consideration of this provision engendered considerable discussion within the Commission. One aspect related to the support for such a provision in state practice; while the Martens clause is well-established as a means of protecting persons, its application in the context of environmental protection is far less established. Other than references to scholarly writings, the main sources cited by the Commission's commentary are the 1992 Guidelines for Military Manuals and Instructions on the Protection of the Environment in Times of Armed Conflict, developed under the auspices of the International Committee of the Red Cross, and the ensuing 1994 UN General Assembly resolution calling upon states to adopt those guidelines into their military manuals and instructions. ${ }^{27}$ Yet, there seems little evidence that since 1994 states, in fact, have included a Martens Clause in favor of the environment in their military manuals. For example, the U.S. Department of Defense Law of War Manual, updated in 2016, has not done so. ${ }^{28}$ Nor have any international agreements contained such a clause, including the 1976 Convention on the Prohibition of Military or Any Other Hostile Use of Environmental Modification Techniques (ENMOD Convention). ${ }^{29}$ Another aspect of the Commission's debate was whether such a draft principle is a good statement as a matter of legal-policy, in particular whether it might detract from the centrality of the protection of persons in times of armed conflict.

Other draft principles in Part Three derive from or are inspired by provisions of the 1907 Hague Regulations, ${ }^{30}$ the 1949 Fourth Geneva Convention, ${ }^{31}$ the 1977 Protocol Additional to the Geneva Conventions of 12 August 1949, and Relating to the Protection of Victims of International

\footnotetext{
262019 Report, supra note 1, at 212-13.

272019 Report, supra note 1, at 248-49, para. (5).

${ }^{28}$ See generally U.S. Department of Defense Law of War Manual (updated 2016).

${ }^{29}$ Convention on the Prohibition of Military or Any Other Hostile Use of Environmental Modification Techniques (New York, 10 December 1976), United Nations, Treaty Series, vol. 1108, No. 17119, p. 151.

${ }^{30}$ Convention (IV) respecting the Laws and Customs of War on Land (Hague Convention IV), Annex to the Convention: Regulations concerning the Laws and Customs of War on Land (Hague Regulations), The Hague, Oct.

${ }^{31}$ Geneva Convention relative to the Protection of Civilian Persons in Time of War (Geneva, 12 August 1949), United Nations, Treaty Series, vol. 75, No. 973, p. 287.
} $18,1907$. 
Armed Conflicts (Additional Protocol I) ${ }^{32}$ and the ENMOD Convention, but with an emphasis on environmental protection. Such principles address the general need to respect and protect the natural environment in accordance with the law of armed conflict (draft principle 13); the application of "principles and rules on distinction, proportionality, military necessity and precautions in attack" in this regard (draft principles 14-15); protection from attack of protected environmental/cultural zones (draft principle 17); the prohibition on pillage of natural resources (draft principle 18); and obligations arising under the ENMOD Convention (draft principle 19). Draft principle 16, which expresses a prohibition of reprisals against the natural environment, received a mixed reaction within the Commission, as is clear from the associated commentary. ${ }^{33}$ The commentary explains that the "divergent views centred around three main points: (a) the link between draft principle 16 and article 51 of Additional Protocol I; (b) whether or not the prohibition of reprisals against the environment reflected customary law; and (c) if so, whether both international and non-international armed conflicts were covered by such a customary law rule." 34 The United States, for example, has not ratified Additional Protocol I and has repeatedly stated that it does not regard the rule expressed in article 51 regarding reprisals against civilians ${ }^{35}$ as reflecting customary international law. ${ }^{36}$

Part Four ${ }^{37}$ focuses on principles applicable in situations of occupied territory, indicating certain general obligations of the occupying power vis-à-vis the environment in the occupied territory (draft principle 20), the need for the occupying power to administer natural resources in the occupied territory in a way that ensures their sustainable use and minimizes environmental harm (draft principle 21), and the requirement that the occupying power "exercise due diligence to ensure that activities in the occupied territory do not cause significant harm to the environment of areas beyond the occupied territory" (draft principle 22).

Part Five ${ }^{38}$ addresses principles applicable after armed conflict has occurred. Such principles concern: including in peace agreements, where appropriate, matters relating to the restoration and protection of the environment damaged by the conflict (draft principle 23); sharing and granting of access to relevant information for States and international organizations, to facilitate remedial measures (draft principle 24); undertaking post-conflict environmental assessments and remedial measures (draft principle 25); provision of relief and assistance when the source of the environmental damage is unknown (draft principle 26); and removing or rendering harmless remnants of war on land or at sea (draft principles 27-28).

Having completed the first reading, the Commission transmitted the draft principles, through the UN Secretary-General, to governments, international organizations (including from the United Nations and its Environment Program), and others including the International

\footnotetext{
32 Protocol Additional to the Geneva Conventions of 12 August 1949, and Relating to the Protection of Victims of International Armed Conflicts, June 8, 1977, 1125 UNTS 3, 16 ILM 1391 [hereinafter Additional

Protocol I].

332019 Report, supra note 1, at 257-60, paras. (2)-(10).

${ }^{34} I d$., at 257, para. (2).

35 Article 51, paragraph 6, of Additional Protocol I provides: “Attacks against the civilian population or civilians by way of reprisals are prohibited."

${ }^{36}$ See Murphy, Sixty-Seventh Session, supra note 21, at 839-41.

372019 Report, supra note 1, at 213-14.

382019 Report, supra note 1, at 214-15.
} 
Committee of the Red Cross and the Environmental Law Institute) for comments and observations, with the request that they be submitted by December 2020. ${ }^{39}$ The Commission is expected to return to this topic for second reading in 2021.

\section{CRIMES AGAINST HUMANITY}

The Commission completed on second reading the draft articles on prevention and punishment of crimes against humanity (comprising a draft preamble, 15 draft articles and a draft annex) during the seventy-first session, under the guidance of special rapporteur Sean D. Murphy (United States; the present author). ${ }^{40}$ During the session, the Commission had before it the fourth report of the special rapporteur, which focused on analyzing comments received by the Commission since the adoption of the first reading text in $2017 .{ }^{41}$

Those comments were extensive: oral comments were made by fifty-two states during the debate in the UN Sixth (Legal) Committee in the fall of 2017, while written comments were received from approximately 40 states. ${ }^{42}$ In addition, written comments were received from seven international organizations (or offices thereof) and some twenty special procedures mandate holders (such as special rapporteurs of the UN Human Rights Council). ${ }^{43}$ Finally, views were submitted by or on behalf of approximately 700 non-governmental organizations or individuals. ${ }^{44}$ Based on such comments, the Commission made certain adjustments to the first reading text and its commentary. The principal changes were as follows.

First, a new third paragraph was added to the draft preamble: "Recalling the principles of international law embodied in the Charter of the United Nations, ...." ${ }^{45}$ The commentary explains that such principles

include the principle of the sovereign equality of all States and the principle that States shall refrain in their international relations from the threat or use of force against the territorial integrity or political independence of any State, or in any other manner inconsistent with the purposes of the United Nations. Thus, this preambular paragraph emphasizes, as does draft article 4, that although crimes against humanity may threaten the peace, security and well-

392019 Report, supra note 1, at 5, para. (17).

${ }^{40}$ For the complete set of the final articles and commentaries, see 2019 Report, supra note 1, at 215-96. For discussion of prior work on these conclusions, see Murphy, Sixty-Seventh Session, supra note 21, at 835-36; Murphy, Sixty-Eighth Session, supra note 2, at 727-29; Murphy, Sixty-Ninth Session, supra note 2, at 988-90.

${ }^{41}$ See International Law Commission, Fourth Report on Crimes against Humanity, UN Doc. A/CN.4/725 (Feb. 18, 2019) (prepared by Special Rapporteur Sean D. Murphy) [hereinafter Fourth Report on Crimes against Humanity].

${ }^{42} I d$. at 4-5, paras. 4-5.

${ }^{43} I d$. at 5, para. 6. The Commission's secretariat compiled these written comments by governments, international organizations, and others (and organized them article-by-article), in Crimes against humanity: Comments and observations received from Governments, international organizations and others, UN Doc. A/CN.4/726 (Jan. 21, 2019); addendum 1, UN Doc. A/CN.4/726/Add.1 (Mar. 28, 2019); addendum 2 , A/CN.4/726/Add.2 (May 2, 2019). Verbatim copies of these comments may be accessed at http://legal.un.org/ilc/guide/7_7.shtml.

${ }^{44}$ Fourth Report on Crimes against Humanity, supra note 41, at 5-6, para. 7.

452019 Report, supra note 1, at 11 (draft pmbl. para. 3). 
being of the world, the prevention and punishment of such crimes must be undertaken in conformity with international law, including the rules on the threat or use of force. ${ }^{46}$

Second, draft article 2 on the definition of crimes against humanity addresses in subparagraph 1(h) the act of "persecution", by which is meant persecution occurring against a group or collectivity on certain specified grounds, such as race, ethnicity or gender. ${ }^{47}$ The Commission deleted from this subparagraph a clause that had been based upon the 1998 Rome Statute, which refers to such persecution when it occurs "in connection with" crimes that are within the jurisdiction of the International Criminal Court. ${ }^{48}$ According to the Commission's commentary, the "Commission considered this clause to be designed to establish a specific jurisdiction of the International Criminal Court and not to indicate the scope of what should constitute persecution as a crime against humanity more generally or for purposes of national law. Such a clause is not used as a jurisdictional threshold for other contemporary international criminal tribunals." 49 The Commission also deleted from draft article 2 a definition of "gender" that appears in the Rome Statute. ${ }^{50}$ In this regard, the commentary explains:

Since the adoption of the Rome Statute, several developments in international human rights law and international criminal law have occurred, reflecting the current understanding as to the meaning of the term "gender", notably: the 2004 guidance document by the International Committee of the Red Cross; the 2010 Committee on the Elimination of Discrimination against Women general recommendation No. 28; the 2011 Council of Europe Convention on Preventing and Combating Violence against Women and Domestic Violence; and recent reports of United Nations special rapporteurs or independent experts. Moreover, the Office of the Prosecutor of the International Criminal Court in 2014 issued the "Policy paper on sexual and gender-based crimes", which states:

Article 7 (3) of the Statute defines "gender" as referring to "the two sexes, male and female, within the context of society. The term 'gender' does not indicate any meaning different from the above." This definition acknowledges the social construction of gender and the accompanying roles, behaviours, activities, and attributes assigned to women and men, and girls and boys. The Office will apply and interpret this in accordance with internationally recognised human rights pursuant to article 21(3) [of the 1998 Rome Statute].

A similar approach of viewing gender as a socially constructed (rather than biological) concept has been taken by various other international authorities and in the jurisprudence of international criminal courts and tribunals.

\footnotetext{
${ }^{46} I d$. at 24, para. (4).

${ }^{47} \mathrm{Id}$. at 12 (draft article 2, para. 1(h)).

${ }^{48}$ The analogous portion of the Rome Statute, see Rome Statute, art. 7, para. 1(h), criminalizes acts of persecution when undertaken in connection with "any crime within the jurisdiction of the Court"; those crimes are genocide, crimes against humanity, war crimes, and the crime of aggression.

492019 Report, supra note 1, at 44, para. (38).

50 See Rome Statute, art. 7, para. 3 ("For the purpose of this Statute, it is understood that the term 'gender' refers to the two sexes, male and female, within the context of society. The term 'gender' does not indicate any meaning different from the above.").
} 
... Accordingly, the Commission decided not to include the definition of "gender" found in article 7, paragraph 3, of the 1998 Rome Statute, thereby allowing the term to be applied for the purposes of the present draft articles based on an evolving understanding as to its meaning. ${ }^{51}$

Third, the Commission expressly included in draft article 3 an obligation that in the first reading text was regarded as implicit: "Each State has the obligation not to engage in acts that constitute crimes against humanity." The commentary explains that this obligation requires a State not to commit such acts through its own organs (or by other means attributable to the State), as well as not to aid or assist, or to direct, control or coerce, another state in the commission of such an act. $^{52}$

Fourth, the Commission streamlined its formulation of the rule on command responsibility, which appears in draft article 6 . The new formulation, which builds upon the standard that appears in Additional Protocol $\mathrm{I}^{53}$ the statutes of the international criminal tribunals for the former Yugoslavia and for Rwanda ${ }^{54}$ and the 2005 ICRC study on Customary International Humanitarian Law ${ }^{55}$ reads:

Each State shall also take the necessary measures to ensure that commanders and other superiors are criminally responsible for crimes against humanity committed by their subordinates if they knew, or had reason to know, that the subordinates were about to commit or were committing such crimes and did not take all necessary and reasonable measures in their power to prevent their commission, or if such crimes had been committed, to punish the persons responsible. ${ }^{56}$

Fifth, the Commission clarified that the provision on reparation for victims of crimes against humanity applies only to states that have either committed the acts constituting crimes against humanity or in whose territory such crimes were committed. ${ }^{57}$

Sixth, the Commission added a provision to the draft article on mutual legal assistance that is designed to address state cooperation with "international mechanisms" established by international organizations to gather evidence. One example of such an international mechanism is the International, Impartial and Independent Mechanism to Assist in the Investigation and Prosecution of Persons Responsible for the Most Serious Crimes under International Law Committed in the Syrian Arab Republic since March 2011. Established by the UN General Assembly in 2016, this mechanism has a mandate

${ }^{51} 2019$ Report, supra note 1, at 45-46, paras. (41)-(42) (citations omitted).

522019 Report, supra note 1, at 48-49, paras. (2)-(6).

${ }^{53}$ See Additional Protocol I, supra note XX, art. 86, para. 2.

${ }^{54}$ See Statute of the International Criminal Tribunal for the Former Yugoslavia, art. 7, para. 3; Statute of the International Criminal Tribunal for Rwanda, art. 6, para. 3.

${ }^{55}$ JeAN-MARIE HENCKAERTS \& LOUISE DOSWALD-BECK, CuSTOMARy INTERNATIONAL HuMANITARIAN LAW, VOL. 1: RULES 558-63 (2005) (Rule 153).

${ }^{56} \mathrm{Id}$. at 14 (draft article 6, para. 3 ).

${ }^{57} I d$. at 16 (draft article 12, para. 3). 
to collect, consolidate, preserve and analyse evidence of violations of international humanitarian law and human rights violations and abuses and to prepare files in order to facilitate and expedite fair and independent criminal proceedings, in accordance with international law standards, in national, regional or international courts or tribunals that have or may in the future have jurisdiction over these crimes, in accordance with international law. ${ }^{58}$

Obviously, such a mandate encompasses evidence of crimes against humanity. In 2017, the UN Security Council passed a similar resolution for pursuing accountability with respect to crimes against humanity (and other crimes) perpetrated in Iraq by the Islamic State (also called ISIS, ISIL or Da'esh). Specifically, the Council requested the Secretary-General

to establish an Investigative Team, headed by a Special Adviser, to support domestic efforts to hold ISIL (Da'esh) accountable by collecting, preserving, and storing evidence in Iraq of acts that may amount to war crimes, crimes against humanity and genocide committed by the terrorist group ISIL (Da'esh) in Iraq ... to ensure the broadest possible use before national courts, and complementing investigations being carried out by the Iraqi authorities, or investigations carried out by authorities in third countries at their request. ${ }^{59}$

In 2018, the Human Rights Council also established a mechanism with respect to Myanmar. The Council requested that this mechanism "prepare files in order to facilitate and expedite fair and independent criminal proceedings, in accordance with international law standards, in national, regional or international courts or tribunals that have or may in the future have jurisdiction over these crimes." 60

In light of such developments, the Commission included in the draft articles a provision that provides: "States shall consider, as appropriate, entering into agreements or arrangements with international mechanisms that are established by the United Nations or by other international organizations and that have a mandate to collect evidence with respect to crimes against humanity."61

Having completed the second reading, the Commission transmitted the entire set of draft articles on prevention and punishment of crimes against humanity, together with commentaries thereto, to the UN General Assembly. Further, the Commission recommended the elaboration of a convention by the General Assembly or by an international conference of plenipotentiaries on the basis of the draft articles. ${ }^{62}$

\section{OTHER Topics AdDRESSED DURING THE SEVENTIETH Session}

Succession of States with Respect to State Responsibility

${ }^{58}$ General Assembly resolution 71/248, para. 4 (Dec. 21, 2016). For further information on this mechanism, see https://iiim.un.org.

${ }^{59}$ Security Council resolution 2379, para. 2 (Sept. 21, 2017).

${ }^{60}$ Human Rights Council resolution 39/2, para. 22 (Sept. 27, 2018).

612019 Report, supra note 1, at 16 (draft article 14, para. 9).

${ }^{62}$ Id. at 5, para. (13). 
In 2016, the Commission moved the topic of succession of states in respect of state responsibility onto the current program of work and appointed Pavel Šturma (Czech Republic) as special rapporteur. ${ }^{63}$ Generally speaking, this topic is analyzing the rules on state responsibility applicable to the rights and obligations of a predecessor state, a successor state, and third states, in situations where a succession of states occurs. ${ }^{64}$ The Commission's progress since 2016, however, has been slow. Only during the seventy-first session were initial draft articles on scope (draft article 1), use of terms (draft article 2), and application of the draft articles solely to a succession occurring in conformity with international law (draft article 5) adopted by the Commission with commentary. ${ }^{65}$

The Commission had before it during this session the fourth report of the special rapporteur, which focused on the bringing of claims for reparation in different categories of state succession, as well as traditional and modern approaches to reparation for injury arising from internationally wrongful acts committed against the nationals of the predecessor state. ${ }^{66}$ Yet, while that report was debated in the plenary and resulted in the referral of certain proposals to the drafting committee, ${ }^{67}$ the drafting committee was continuing to work on proposals of the special rapporteur originally made in his second report from $2017 .{ }^{68}$ That work resulted in the adoption of three new draft articles by the drafting committee. ${ }^{69}$ Draft article 7 on "Acts having a continuing character" reads as follows:

When an internationally wrongful act of a successor State is of a continuing character in relation to an internationally wrongful act of a predecessor State, the international responsibility of the successor State extends only to the consequences of its own act after the date of the succession of States. If and to the extent that the successor State acknowledges and adopts the act of the predecessor State as its own, the international responsibility of the successor State also extends to the consequences of such act.

Further, the drafting committee adopted draft article 8 on "Attribution of conduct of an insurrectional or other movement," which reads:

${ }^{63}$ Report of the International Law Commission on the Work of Its Sixty-Seventh Session, supra note 4, at 138, para. 286. For discussion of prior work on this topic, see Murphy, Sixty-Ninth Session, supra note 2, at 990-92; Murphy, Seventieth Session, supra note 2, YY-ZZ.

${ }^{64}$ For the syllabus of the topic, see Report of the International Law Commission on the Work of Its Sixty-Eighth Session, UN GAOR, 71 st Sess., Supp. No. 10, at 400, Annex B, UN Doc. A/71/10 (Sept. 19, 2016). In recent years, other bodies have also studied this issue. See International Law Association, Report of the Seventy-Third Conference, Rio de Janeiro, Aug. 17-21 2008, at 250 et seq.; Institute of International Law, Fourteenth Commission, State Succession in Matters of State Responsibility, Provisional Report of the Rapporteur, Mr. Marcelo G. Kohen; Institute of International Law, Resolution on Succession of States in Matters of International Responsibility, Aug. $28,2015$.

652019 Report, supra note 1, at 306-09, paras. 117-18.

66 See International Law Commission, Third Report on Succession of States in Respect of State Responsibility, UN Doc. A/CN.4/ 731* (May 2, 2019) (prepared by Special Rapporteur Pavel Šturma).

672019 Report, supra note 1, at 299, para. 77.

68 See International Law Commission, Second Report on Succession of States in Respect of State Responsibility, UN Doc. A/CN.4/719 (Apr. 6, 2018) (prepared by Special Rapporteur Pavel Šturma) [hereinafter Second Report on Succession of States in Respect of State Responsibility].

${ }^{69}$ See Succession of States in respect of State responsibility: Text of draft articles 7, 8 and 9 provisionally adopted by the Drafting Committee at the seventy-first session, UN Doc. A/CN.4/L.939/Add.1 (July 24, 2019). 
1. The conduct of a movement, insurrectional or other, which succeeds in establishing a new State in part of the territory of a predecessor State or in a territory under its administration shall be considered an act of the new State under international law.

2. Paragraph 1 is without prejudice to the attribution to the predecessor State of any conduct, however related to that of the movement concerned, which is to be considered an act of that State by virtue of the rules on responsibility of States for internationally wrongful acts.

Finally, the drafting committee adopted draft article 9 on "Cases of succession of States when the predecessor State continues to exist." It reads:

1. When an internationally wrongful act has been committed by a predecessor State before the date of succession of States, and the predecessor State continues to exist, an injured State continues to be entitled to invoke the responsibility of the predecessor State even after the date of succession:

(a) when part of the territory of the predecessor State, or any territory for the international relations of which the predecessor State is responsible, becomes part of the territory of another State;

(b) when a part or parts of the territory of the predecessor State separate to form one or more States; or

(c) when a successor State is a newly independent State the territory of which immediately before the date of the succession of States was a dependent territory for the international relations of which the predecessor State was responsible.

2. In particular circumstances, the injured State and the successor State shall endeavor to reach an agreement for addressing the injury.

3. Paragraphs 1 and 2 are without prejudice to any apportionment or other agreement between the predecessor State and the successor State when implementing paragraphs 1 and 2 .

As explained by the chair of the drafting committee, the "main element of paragraph 1 [of draft article 9] is temporal. It aims at indicating that the entitlement of the injured State to invoke the responsibility of a predecessor State is not affected after the date of a succession of States if the predecessor State still remains."70 By contrast, the

\footnotetext{
${ }^{70}$ Succession of States in respect of State responsibility, Statement of the Chair of the Drafting Committee Mr. Claudio Grossman Guiloff, at 8 (July 31, 2019), at http://legal.un.org/docs/?path=../ilc/documentation/english/statements/2019_dc_chairman_statement_sosr.pdf\&lang $=\mathrm{E}$.
} 
purpose of paragraph 2 is to address exceptional situations where there is a direct link between the act or its consequences and the territory of the successor State or States. In such circumstances, the predecessor State may not be in a position to address the injury alone and may need the cooperation with the successor State to do so. ... The purpose of paragraph 2 is not to create obligations entailing the automatic transfer of obligations to the successor State, but instead is to signal the possibility for the successor State to reach an agreement with the injured State for addressing the injury. This could take a variety of forms depending on the factual situation, the nature of the internationally wrongful act, and the link between its consequences and the successor State. The purpose of paragraph 2 is also to signal that the consequences of the internationally wrongful act do not disappear simply because of the succession of States. ${ }^{71}$

\section{Immunity of State Officials from Foreign Criminal Jurisdiction}

Toward the end of the seventieth session in 2018, the Commission received the sixth report on the topic of immunity of State officials from foreign criminal jurisdiction, submitted by its second special rapporteur for this topic, Concepción Escobar Hernández (Spain). ${ }^{72}$ The report discussed in general terms certain procedural issues: when it is that immunity should be considered by the authorities of the forum state; the acts of those authorities that are affected by immunity; and the determination of immunity. The sixth report made no proposals for additional draft articles. The Commission commenced a debate on the sixth report, but was not able to conclude it before the end of the seventieth session.

Consequently, the debate on that report continued during the seventy-first session, but was merged with the debate on a new, seventh report by the special rapporteur, ${ }^{73}$ which also addressed procedural issues and safeguards. The seventh report proposed a series of new draft articles on: consideration of immunity by the forum state at an early stage in the process; notification of and exchange of information with the state of the official; invocation and waiver of immunity by the state of the official; and determination of immunity by the courts of the forum state. ${ }^{74}$ While the plenary debated and referred these proposals to the drafting committee, the drafting committee did not adopt any of them during the seventy-first session due to a lack of time.

The debate revealed uncertainty among the members as to whether the procedural provisions being considered would apply in situations where draft article 7 was at issue (draft

\footnotetext{
${ }^{71} I d$.

${ }^{72}$ International Law Commission, Sixth Report on Immunity of State Officials from Foreign Criminal Jurisdiction, UN Doc. A/CN.4/722 (June 12, 2018) (prepared by Special Rapporteur Concepción Escobar Hernández) [hereinafter Sixth Report on Immunity of State Officials from Foreign Criminal Jurisdiction]. For discussion of prior work on this topic, see Sean D. Murphy, The Expulsion of Aliens and Other Topics: The SixtyFourth Session of the International Law Commission, 107 AJIL 164, 169-71 (2013) [hereinafter Murphy, SixtyFourth Session]; Murphy, Sixty-Fifth Session, supra note 21, at 41-48; Murphy, Sixty-Sixth Session, supra note 21, at 139-40; Murphy, Sixty-Seventh Session, supra note 21, at 842; Murphy, Sixty-Eighth Session, supra note 2, at 732-42; Murphy, Sixty-Ninth Session, supra note 2, at 981-88; Murphy, Seventieth Session, supra note 2, YY-ZZ.

${ }^{73}$ International Law Commission, Seventh Report on Immunity of State Officials from Foreign Criminal Jurisdiction, UN Doc. A/CN.4/722 (June 12, 2018) (prepared by Special Rapporteur Concepción Escobar Hernández) [hereinafter Seventh Report on Immunity of State Officials from Foreign Criminal Jurisdiction].

${ }^{74}$ See id. at 72-75, Annex II.
} 
article 7 maintains that immunity ratione materiae from the exercise of foreign criminal jurisdiction "shall not apply in respect of" the crime of genocide, crimes against humanity, war crimes, the crime of apartheid, torture, and enforced disappearance.) The concern was that, if such immunity "shall not apply" in situations where a person is alleged to have committed one of the listed crimes, then arguably there was no need to "consider" or "determine" the issue of immunity ratione materiae by the forum state (nor even any ability of the State of the official to waive such immunity), as the non-existence of any immunity already had been decided based purely on the nature of the allegation. In an effort to address this concern, the drafting committee adopted a new draft article 8 ante, which would be located at the beginning of the procedural provisions, and which reads:

The procedural provisions and safeguards in this Part shall be applicable in relation to any criminal proceeding against a foreign State official, current or former, that concerns any of the draft articles contained in Part Two and Part Three of the present draft articles, including to the determination of whether immunity applies or does not apply under any of the draft articles. ${ }^{75}$

The special rapporteur intends to prepare a final report for the seventy-second session in 2020 , in the hope of completing a first reading of this topic during that session. ${ }^{76}$

\section{General Principles of Law}

In 2018, the Commission moved the topic of general principles of law onto the current program of work and appointed Marcelo Vázquez-Bermúdez (Ecuador) as special rapporteur. ${ }^{77}$ Generally speaking, this topic is analyzing the third main source of international law, as reflected in article 38, paragraph 1(c) of the Statute of the International Court of Justice: "the general principles of law recognized by civilized nations." "78 At the seventy-first session, the Commission had before it the first report of the special rapporteur, which was general in nature, but made proposals for three draft conclusions. ${ }^{79}$ While the proposals were referred to the drafting committee, there was only time during the session to adopt in the drafting committee an initial draft conclusion 1 on "scope." 80

\footnotetext{
${ }^{75}$ Immunity of State officials from foreign criminal jurisdiction: Text and title of the draft article 8 ante provisionally adopted by the Drafting Committee, UN Doc. A/CN.4/L.940 (July 31, 2019). 177.

${ }^{76}$ Seventh Report on Immunity of State Officials from Foreign Criminal Jurisdiction, supra note 73, at 68, para.

77 See Report of the International Law Commission on the Work of Its Seventieth Session, UN GAOR, 73rd Sess., Supp. No. 10, at 299, para. 363, UN Doc. A/73/10 (Sept. 3, 2018) [hereinafter 2018 Report]. For the syllabus of the topic, see Report of the International Law Commission on the Work of Its Sixty-Ninth Session, UN GAOR, 72rd Sess., Supp. No. 10, at 224, Annex A, UN Doc. A/72/10 (Sept. 3, 2017) [hereinafter 2017 Report]

${ }^{78}$ Statute of the International Court of Justice, art. 38, para. 1(c).

${ }^{79}$ See International Law Commission, First Report on General Principles of Law, UN Doc. A/CN.4/732 (Apr. 5, 2019) (prepared by Special Rapporteur Marcelo Vázquez-Bermúdez) [hereinafter First Report on General Principles of Law].

${ }^{80}$ See General principles of law: Statement of the Chair of the Drafting Committee, Mr. Claudio Grossman Guiloff, at 2 (Aug. 7, 2019) ("The present draft conclusions concern general principles of law as a source of international law.").
} 
The debate within the Commission revealed some differences of views as to the origins of general principles of law. The special rapporteur's proposal in this regard asserted that "general principles of law comprise those: (a) derived from national legal systems; [and] (b) formed within the international legal system." 81

The special rapporteur's analysis found that there is an overall acceptance by states and others that general principles of law, within the meaning of ICJ Statute Article 38, paragraph 1(c), are derived from national legal systems. ${ }^{82}$ Further, the report indicates that, for this category, there needs to be a two-stage process. First, there must be an emergence of a principle of law common to the national legal systems of states. Second, there must be a transposition of that general principle of law to the domain of international law. This second stage is required because there are legal principles common to national legal systems that are not appropriately transposed to international law. ${ }^{83}$

Differences of views emerged within the Commission, however, with respect to the second category: general principles of law formed solely within the international legal system. ${ }^{84}$ Some members expressed doubts about such an origin of general principles of law, a view that is reflected as well in some scholarship. ${ }^{85}$ The practice presented by the first report in support of this second category was more limited than for the first category, and for each example it was not always clear that a "general principle of law" within the meaning of ICJ Statute Article 38, paragraph 1(c) was at issue. For example, while the International Court did refer to certain "principles" in the Corfu Channel case, in the advisory opinion on Reservations to the Convention on Genocide, and in the

${ }^{81}$ First Report on General Principles of Law, supra note 79, at 73, para. 253.

${ }^{82}$ Id. at XX-YY, paras. 190-230.

${ }^{83}$ For example, in most systems of property law worldwide, there is a legal principle of prescriptive easement, whereby a property owner must accord a right of passage to someone who has traversed the property for a long time without any objection by the property owner. That legal principle, however, has not gained any traction in the domain of international law, most likely because it does not sit well with the concept of the territorial sovereignty of a State. In Right of Passage over Indian Territory (Portugal v. India), 1960 I.C.J. 6, Portugal argued that it had a right to overland access from the sea to enclaves of its territory located within India, based in part on a general principle of law. The Court declined to apply any such principle, finding that instead there was sufficient bilateral practice to address the issue. It noted that where it "finds a practice clearly established between two States which was accepted by the Parties as governing the relations between them, the Court must attribute decisive effect to that practice for the purpose of determining their specific rights and obligations. Such a particular practice must prevail over any general rules." Id. at 44.

${ }^{84}$ First Report on General Principles of Law, supra note 79, at XX-YY, paras. 231-53.

${ }^{85}$ See, for example, Michelle Biddulph \& Dwight Newman, A Contextualized Account of General Principles of International Law, 26 Pace Int'l L. Rev. 286, 292 (2014) (arguing that there is a purely "domestic approach" and a "hybrid approach" to analyzing general principles, with most deriving general principles from domestic legal systems and some also taking account the structure of the international system itself); Jean d'Aspremont, Formalism and the Sources of International Law: A Theory of the Ascertainment of Legal Rules 97-98, 171 (2011) (referring only to general principles of law as derived from domestic law); Jaye Ellis, General Principles and Comparative Law, 22 EJIL 949, 953 (2011) (“[G]eneral principles of international law are today understood as principles derived from municipal law."); Johan G. Lammers, "General Principles of Law Recognized by Civilized Nations," in Essays on the Development of the International Legal Order, at 53, 56 (Frits Kalshoven et al., eds., 1980) (noting that many scholars believe that the general principles "consist only of principles generally recognized-implicitly or explicitly - in national legal systems or of principles basic to law in general"); Bin Cheng, General Principles of Law as Applied by International Courts and Tribunals 25 (1953); Hersch Lauterpacht, Private Law Sources and Analogies of International Law 71 (1927) ("[G]eneral principles of law are for the most practical purposes identical with general principles of private law"). 
Frontier Dispute case, ${ }^{86}$ in each instance the Court refrained from mentioning Article 38 , paragraph 1(c), leaving it unclear whether that source of law was, in fact, at issue. Indeed, it is not overly difficult to conceive of some of the "principles" identified in those cases as rules emanating from customary international law or from treaty law. Likewise, some of the sources referred to in the first report in support of this category - even if clearly referring to a general principle of law within the meaning of ICJ Statute Article 38, paragraph 1(c)- might be understood as doing so in the context of principles of law derived from national legal systems. For example, references to general principles of law as identified in the post-war Nürnberg trials and in the International Law Commission's 1950 Nürnberg principles might be understood in this way. ${ }^{87}$ Finally, many principles of law that might be regarded as "derived from" the international law system do have counterparts in national systems of law, making it somewhat difficult to disentangle the two. ${ }^{88}$ Indeed, legal principles of pacta sunt servanda ${ }^{89}$ or of res judicata ${ }^{90}$ or of lex posterior derogat priori $^{91}$ appear to be principles intrinsic to the very idea of law, such that they necessarily exist in both the national and international legal systems.

If general principles of law can be formed solely within the international legal system, then a key question is how one determines that such a general principle of law, in fact, has been formed. Presumably states in some sense must have recognized or accepted the existence of the general principle of law as binding upon them. ${ }^{92}$ Other types of limits might be posited as well. ${ }^{93}$ For example, one might maintain that this category is limited to those general principles of law that are unique to the very existence of a legal system of sovereign states, such as a general principle of law on non-intervention or a general principle of law on sovereign equality. But, even here, while such "principles" are often referred to and relied upon by states, there are reasons to see such

${ }^{86}$ See First Report on General Principles of Law, supra note 79, at XX-YY, paras. 236, 237, $242-43$.

${ }^{87} \mathrm{Id}$. at XX-YY, paras. 248-49. For example, footnote 422 of the First Report quotes the International Military Tribunal as referring to "the general principles of justice applied by jurists and practised by military courts," which seems to be a reference to national legal systems.

${ }^{88}$ For example, the principle of ex turpi causa non oritur actio essentially provides that one party to a dispute cannot avail itself of the fact that the other party has not fulfilled some obligation, if the first party has, by some illegal act, prevented the latter from fulfilling the obligation in question. In the Factory at Chorzów case, the Permanent Court said that such a principle was "generally accepted in the jurisprudence of international arbitration, as well as by municipal courts," [citation needed], thereby suggesting that the principle may have emerged from within both categories. The International Court of Justice recognized the existence and origins of this principle in both Gabčikovo-Nagymaros Project (Hungary/Slovakia), Judgment, I.C.J. Reports 1997, p. 67, para. 110, and more recently in Jadhav (India v. Pakistan), Judgment, I.C.J. Reports 2019, para. 62.

${ }^{89}$ Agreements must be kept.

${ }^{90}$ A final judgment on the merits is conclusive as between the parties.

91 The later supersedes the earlier law, if both have the same source.

92 See, for example, Giorgo Gaja, "General Principles in the Jurisprudence of the ICJ," in General Principles and the Coherence of International Law, at 39-43 (Mads Andenas et al., eds., 2019) (stating that general principles of law pertaining to international law, for which there is no analogue in domestic law, require recognition or acceptance by States that reflect their attitude to be bound by such principles)

${ }^{93}$ See, for example, Charles T. Kotuby, Jr. \& Luke A. Sobota, General Principles of Law and International Due Process: Principles and Norms Applicable in Transnational Disputes 17-29 (2017) (stating that general principles of law of both varieties must be general, universal, and international); Hugh Thirlway, The Sources of International Law 99-115 (2014) (stating that the method for identifying general principles of law from the international legal system ought to be guided by the method for those originating from municipal legal systems and that both categories of general principles of law "must represent a shared approach to a general need of a strictly legal nature" such as logical necessity, the requirements of any legal system, equity, and the avoidance of non liquet). 
principles as arising from treaty law or customary international law, rather than from a third source of law.

\section{Sea-Level Rise in Relation to International Law}

During the seventieth session in 2019, the Commission placed on its long-term work program the topic of sea-level rise in relation to international law. ${ }^{94}$ At the seventieth-first session, the Commission decided to move that topic to the active agenda, to be addressed in the context of a study group, ${ }^{95}$ which will be open to all members.

The study group meet for informal consultations and then reported back to the Commission's plenary as to its intentions for the next two years of work. In that regard, the group plans to focus on issues related to the law of the sea during the seventy-second session in 2020, under the co-chairpersonship of Bogdan Aurescu (Romania) and Nilüfer Oral (Turkey). During the seventy-third session in 2021, it intends to focus on issues related to statehood and to the protection of persons affected by sea-level rise, under the co-chairpersonship of Patrícia Galvão Teles (Portugal) and Juan José Ruda Santolaria (Peru). Prior to each session, the co-chairs will prepare an issues paper, which will be discussed over the course of approximately five meetings of the study group at each session, and serve as the basis for further reports by members of the study group. At the end of each session, a report on the study group's work will be presented to the Commission, so that a summary of it may be included in the Commission's annual report. ${ }^{96}$

\section{Provisional Application of Treaties}

At the seventieth session in 2018, the Commission completed the first reading of the topic provisional application of treaties, based on a series of reports by the special rapporteur, Juan Manuel Gómez-Robledo (Mexico). ${ }^{97}$ As such, the Commission is now awaiting comments and observations from states and others, in anticipation of completing the second reading at the seventy-second session in 2020. Although this topic was not on the agenda of the Commission during the seventy-first session, the special rapporteur requested informal consultations with members regarding model clauses that might be adopted by the Commission at second reading as an annex to the Commission's draft conclusions.

In light of those consultations, the special rapporteur proposed draft model clauses for consideration by the Commission at the seventy-second session, which are annexed to the

${ }^{94}$ See Report of the International Law Commission on the Work of Its Seventieth Session, UN GAOR, 73rd Sess., Supp. No. 10, at 326-34, Annex B, UN Doc. A/73/10 (Sept. 3, 2018) [hereinafter 2018 Report]. The topic was proposed by a group of ILC members: Bogdan Aurescu (Romania); Yacouba Cissé (Côte d'Ivoire); Patrica Galvão Teles (Portugal); Nilüfer Oral (Turkey); and Juan José Ruda Santolaria (Peru). For discussion of the addition of the topic to the Commission's long-term work program, see Murphy, Seventieth Session, supra note 2, YY-ZZ.

${ }_{95} 2019$ Report, supra note 1, at 340, para. 265.

${ }^{96} \mathrm{Id}$. at $340-41$ paras. $269-71$.

${ }^{97}$ For discussion of prior work on these draft guidelines, see Murphy, Sixty-Fourth Session, supra note 72, at 171-73; Murphy, Sixty-Fifth Session, supra note 21, at 53-54; Murphy, Sixty-Sixth Session, supra note 21, at 143-44; Murphy, Sixty-Seventh Session, supra note 21, at 822-32; Murphy, Sixty-Eighth Session, supra note 2, at 742-45; Murphy, Sixty-Ninth Session, supra note 2, at 978-80; Murphy, Seventieth Session, supra note 2, YY$\mathrm{ZZ}$. 
Commission's 2019 annual report. ${ }^{98}$ The proposed model clauses are organized based on certain issues that can arise in this context: commencement and termination of the provisional application of a treaty; the form that an agreement on provisional application may take; the ability to opt-in or opt-out of such an agreement; and limitations deriving from the internal law of States or rules of international organizations. Accompanying the special rapporteur's proposed model clauses are footnotes providing examples of actual clauses upon which the model clauses are based.

\section{OTHER DECISIONS}

During the seventieth session, the Commission placed two new topics on its long-term work program: (1) reparation to individuals for gross violations of international human rights law and serious violations of international humanitarian law; ${ }^{99}$ and (2) prevention and repression of piracy and armed robbery at sea. ${ }^{100}$ During the present quinquennium, the Commission may decide to place one or both of these topics on its agenda.

The first topic on reparations for violations of international human rights law (IHRL) and international humanitarian law (IHL) is contemplated as being pursued by appointment of a special rapporteur. The topic proposal notes that there are three domains where such reparations may be observed: inter-State claims; claims before international courts and tribunals; and claims before national courts. ${ }^{101}$ The proposal further indicates:

This project will examine ... the relevant differences existing within the scope of reparations between IHRL and IHL. This includes inter alia state practice, treaties, decisions, recommendations by international organizations, courts and various supervisory organs concerning IHL and IHRL in particular in areas related to emergency situations. This summary of practice related to reparation to individuals shows not only its increasing importance, but also the many different ways States and relevant adjudicating bodies have addressed the issue of reparation to individuals for violations of IHL and IHRL. The Commission's consideration of this topic would therefore have a solid foundation in existing practice in order to provide useful guidance for States and adjudicating bodies, by distilling general principles, aimed at providing further consistency and legitimacy in this area. $^{102}$

The second topic on piracy is also contemplated as being pursued by appointment of a special rapporteur. The topic proposal notes that "today maritime piracy is resurging at a rate without precedent in history as exemplified by maritime piracy committed in Indian Ocean off the coast of Somalia, the Gulf of Guinea, the Singapore and Malacca Straits, the Arabian Peninsula, Caribbean, Celebes, Java, North Yellow, and South China Seas, and the Bay of Bengal."103 Further, "despite the extensive amount of international, regional and national law, there remain important issues of international law that are uncertain or underdeveloped, which could benefit

\footnotetext{
982019 Report, supra note 1, at 353-57, Annex A.

992019 Report, supra note 1, at 358-69, Annex B. The topic was proposed by Claudio Grossman Guiloff (Chile).

${ }^{100} I d$. at 370-94, Annex C. The topic was proposed by Yacouba Cissé (Côte d'Ivoire).

${ }^{101} \mathrm{Id}$. at 359-60, paras. 5-8.

${ }^{102}$ Id. at 361, para. 16.

${ }^{103}$ Id. at 370, para. 2.
} 
from study, codification, and progressive development by the International Law Commission." 104 As such, the "Commission should begin by noting that the core aspects of the topic of maritime piracy has already been codified;" its "objective would not be to seek to alter any of the rules set forth in existing treaties, but would include whether and how States might best implement their treaty obligations."105

${ }^{104} I d$. at 373 , para. 10.

${ }^{105} \mathrm{Id}$. at para. 11. 